\author{
МИРЈАНА КОСТИЋ ГОЛУБИЧИЋ* \\ Филолошки факултет Универзитета у Београду \\ Београд, Србија
}

\title{
БРОЈЕВИ У НАСТАВИ НА БЕОГРАДСКОЈ ПОЛОНИСТИЦИ
}

\begin{abstract}
Предмет овога рада су бројеви, који због неких својих специфичности често бивају предмет интересовања језичких стручњака. Традиционални приступ њиховом проучавању је морфолошки аспект - неоспорно је да они представљају променљиву врсту речи. Њихова семантика, међутим, која је разнолика, упућује нас на то да је за детаљније изучавање ове категорије неопходан комплекснији приступ. Рад показује однос према овој категорији од самих почетака развоја славистичке науке у нас, све до места које ова језичка категорија заузима у данашње време.
\end{abstract}

Кључне речи: бројеви, морфологија, творба речи, синтакса

У години у којој обележавамо 140 година постојања Катедре за славистику, и 122. годишњицу постојања Групе за пољски језик, књижевност и културу (како гласи садашњи назив), пружа нам се прилика да се још једном, кроз подсећање на минуле године нашега постојања и рада, подсетимо и наших професора, и њиховог педагошког и научног доприноса ономе што представља нашу славистичку науку данас.

За тему рада изабрали смо бројеве, врло специфичну лингвистичку категорију која се од пет променљивих врста речи и у писаном, и у усменом језику најређе јавља у тексту. То је само једна од карактеристика бројева. Сем ове чињенице, они су и облички занимљиви, јер се могу јављати у три различита лика - бројеви се у језику могу обележавати на три начина: помоћу арапских цифара, помоћу римских цифара и на словни начин (помоћу графема). Будући да су лингвистичка категорија, најлогичније би било да се значења која они изражавају прикажу помоћу слова, односно графема, које су средство изражавања и других морфолошких категорија. Промена бројева се у оквиру Морфологије (или Облика код Кошутића) увек и даје на овај графемски начин. Када се броје-

*zoran.golubicic@gmail.com 
ви приказују помоћу графема, они не представљају никакав проблем, јер се осећају као саставни део језика, пошто се за изражавање њиховог семантичког садржаја користе графеме - језичка средства изражавања. Најређи начин изражавања су римски бројеви који садрже седам цифара (углавном великих латиничних слова) и који се користе најчешће за означавање године (или годишта) или неког редоследа. Потреба за језичком економичношћу довела је до тога да је данас најчешћи и најбржи начин изражавања појма броја у језику - помоћу цифара, и управо та чињеница доводи до тога да се бројеви тако написани, због другог, «нелингвистичког», односно цифарског начина изражавања, осећају као нешто што не припада у потпуности језичком систему. Поставља се питање да ли цифру којом се изражава број као лингвистичка категорија можемо назвати цифарском графемом, или, да прецизније дефинишемо питање, да ли су и цифре у језику графеме?

Погледајмо какав статус је имала и на који начин се предавала категорија бројева на београдској полонистици од њених почетака па до данашњих дана.

Почеци полонистике у Србији везују се за годину 1895. када је Стојан Новаковић, министар просвете и професор на Великој школи, поставио Радована Кошутића као предавача за пољски језик. ${ }^{1}$ Родоначелник српске полонистике је исте године почео да држи курс из

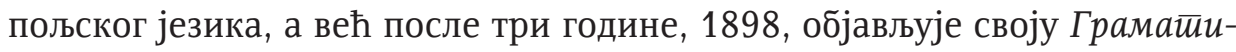
ку йољскоїа језика у којој бројевима, у оквиру дела Облици, посвећује осамнаест страна (89-106, параграфи 212-264), дајући их као четврте по реду после промене именица, промене заменица и промене придева, а испред глагола.

Бројеве је Кошутић поделио на следећи начин, означавајући поделу словима: а. Прости бројеви, б. Збирни бројеви, в. Редни бројеви, г. Остали бројеви. Просте бројеве означава цифрама и словима, наводећи као пример последњег броја 10.000,000 (према тадашњем правопису: dziesięć miljonów); за бројеве 200,000 и 300,000 код њега налазимо данас архаичне облике dwakroć sto tysięcy и trzykroć sto tysięcy (данашњи облици :гласе: dwieście tysięcy, trzysta tysięcy). Уз бројеве siedem/siedemnaście/ siedemdziesiąt и osiem/osiemnaście/osiemdziesiąt даје у загради и алтернативно $\operatorname{siedm} / \mathrm{siedm}$ - и оśm/ośm-).

Говорећи о промени простих бројева, Кошутић каже да „бројеви jeden, dwa, trzy и cztery вреде као придеви, а бројеви од ріе̨с́ па на више - делом као именице, а делом као атрибутивни додаци именицама" ${ }^{2}$.

${ }^{1}$ Јовановић Г., Почеии и развој йолонистиике на беоіраяском универзииеейу. Сто година полонистике у Србији, Београд 1996, стр. 13-19.

${ }^{2}$ Кошутић Р., Грамайика йољскоїа језика. Београд 1898, стр. 90. 
Категорију персоналности и неперсоналности наводи у напомени као о блик А и облик Б, и каже: „први долази само уз лица мушког рода, а други - уза сва остала имена"3. Код промене броја jeden, jedna, jedno истиче разлику у облику акузатива једнине женског рода у односу на промену заменице ten, ta, to (број се завршава назалом задњега реда -а̨, а акузатив заменице назалом предњега реда -е)). Промену броја $d w a, d w i e$ приказује прво у персоналном облику, а за неперсонални даје напоредо облике мушког и средњег, и женског рода, наводећи у напомени податак везан за историју језика и постојање двојине и дајући, на једној страни, двојински облик за мушки, а на другој страни за женски и средњи род. Наводи, такође, драгоцен податак о томе да су облици dwuch (према тадашњем правопису) и dwom настали аналошким путем, први према генитиву и локативу заменица и придева (и аналогијом према облицима trzech и czterech), а други према дативу множине именица. Аналогију према облицима dwoje, dwoisty, dwojaki види и у писању облика dwóch са, како каже, „стегнутим о́”. У вези са променом бројева trzy и cztery (персонални, а затим неперсонални облици) напомиње да је облик инструментала такође настао аналогијом према инструменталу двојине од dwa, oba. У низу бројева од pięć до dziewięćdziesiąt dziewięć даје као прототип промену бројева pięć и јedenaście, и то прво облик Б (неперсонални), а затим А (персонални). Наводи само генитиве бројева dwadzieścia, trzydzieści и czterdzieści, и напомиње да се код бројева од pięćdziesiąt до dziewięćdziesiąt мења само други део (део са десетицама). За брoj sto Кошутић даје и некадашњу промену (по којој се овај број мењао као именица средњег рода). Затим даје оба облика за бројеве dwieście, trzysta и czterysta, и посебно промену броја pięćset. За tysiąc и miljon (са напоменом - читај: миљјон) наводи да се оба облика мењају као именице мушког рода, први по мекој промени (функционално мек сугласник), други по тврдој. У Кошутићево време у употреби су, уместо данашњих синтетичких облика dwieście и trzysta у бројевима dwieście tysięcy и trzysta tysięcy, били аналитички облици dwakroć sto tysięcy и trzykroć sto tysięcy, за које он даје промену, уз опаску да се бројеви dwa и trzy мењају као и обично, „а реч kroć остаје непромењена"4. Вишечлане бројеве (сложене из два броја) назива бројним изразима и напомиње да се мењају оба броја, наводећи као пример промену броја tysiąc pięćset dwadieścia osiem (дакле, четвороцифреног) у персоналном облику.

Кад говори о употреби простих бројева, Кошутић мисли на слагање бројева у роду, броју и падежу са именицама уз које стоје. За број jeden наводи облик за женски род jedna и средњи род jedno (нема персо-

\footnotetext{
${ }^{3}$ Нав. дело, стр. 90

${ }^{4}$ Нав. дело, стр. 94.
} 
налног облика у множини јеdni и неперсоналног јеdne). Код бројева $d w a$, trzy и cztery именица уз коју стоје је у множини и она одређује падеж. За бројеве од pięć до dziewięćdziesiąt dziewięć употреба падежа зависи од тога да ли се уз број налази именица или не (што утиче и на значење). За ове бројеве Кошутић каже да „вреде данас само у номинативу и акузативу као именице, и то средњег рода”, а да су „у осталим падежима изгубили свој именички карактер, па се и именица у таким случајевима не управља више према њима, већ према глаголу, предлогу или другој

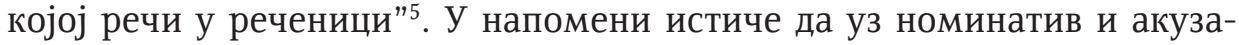
тив бројева са спојем десетица и јединица као што су dwadzieścia jeden, trzydzieści jeden или sto jeden именица стоји у генитиву множине, а код бројева dwadzieścia dwa, trzy, cztery, или trzydzieści $d w a$, trzy, cztery или sto dwa, trzy, cztery именица стоји у номинативу или акузативу множине. Именички карактер сачували су бројеви tysiąc и miljon који захтевају уз себе генитив множине. Кошутић посматра бројеве и са реченичног аспекта, па у напомени каже да се ова два броја у реченици јављају као именице средњег рода. Ако се бројеви већи од ріе̨с́ налазе у функцији субјекта у реченици, таква реченица постаје безлична са бројем у акузативу и предикатом у једнини у средњем роду. Такав предикат захтевају и облици $d w u c h$ (тадашњи правопис), trzech, czterech као варијантни облици у ситуацијама у којима се могу употребити и облици $d w a j$, trzej, czterej који захтевају предикат у множини, у персоналном облику.

У оквиру одељка Прости бројеви визуелно су издвојене Напомене, у којима се дају нпр. важне информације (као што је подела на персонални и неперсонални облик), или се наводе подаци везани за историју језика (рецимо, примери двојине, примери из старопољског језика - у издвојеним Додацима), или се наводе примери аналошких облика, или се обраћа пажња на правописна правила, или се дају варијантни облици, или се наводе фреквентнији облици, или се дају подаци из синтаксе бројева. Интересантан је податак да у оквиру одељка Употреба простих бројева за бројеве јеden, jedna, jedno и dwa, trzy и cztery постоји Задатак: „Показати разлику у употреби ових бројева у пољском и српском језику." Бројеви од ріе̨с́ па навише илустровани су примерима, а на крају одељка о простим бројевима налазе се Примери за вежбање.

Исти принцип Кошутић примењује и у одељку Збирни бројеви, које даје од броја dwoje до dziewiętnaścioro (са напоменом датом у фусноти да се даљи бројеви ретко употребљавају). Збирни бројеви имају само

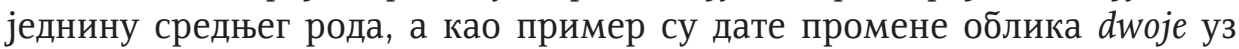
опаску да се тако мења и troje, а да се остали збирни бројеви мењају као

\footnotetext{
${ }^{5}$ Нав. дело, стр. 95.

${ }^{6}$ Нав. дело, стр. 95.
} 
облик czworo. У вези са употребом збирних бројева, Кошутић истиче да се они понашају као именице средњег рода, а именица уз коју стоје је увек у генитиву множине, или у генитиву једнине, уколико нема множину. Употребљавају се уместо простих бројева уз апстрактне именице, уз именице које означавају људе и животиње различитог рода, или уз именице које имају само множину или које чувају стару двојину. Задатак који Кошутић даје у вези са овим бројевима је да се покаже разлика између збирног броја dwoje и бројног придева oboje.

У трећем одељку Редни бројеви Кошутић даје облике од броја pierwszy, pierwsza, pierwsze па до броја dziesięciomiljonowy написане цифрама и графемама. Напомиње да је промена редних бројева придевска и наводи малобројне остатке некадашње именичке промене (од којих су неки облици данас архаични и не употребљавају се у савременом језику, као што је póttora у мушком и средњем роду и póttory у женском, данас: póttora, półtorej). Даје важну напомену да су код двоцифрених бројних израза оба броја редна, а код троцифрених и вишецифрених бројних израза само два последња броја „имају редни облик”7. Када је реч о употреби редних бројева, истиче да се они слажу са именицом уз коју стоје у роду, броју и падежу. У оквиру редних бројева, у посебан одељак издвојено је Казивање година, дана и часова. За године се наводе оба начина изражавања: са предлогом $w$ или са генитивом, а ако се наводи и месец и година, начин изражавања је само помоћу генитива. Генитив се употребљава и у одговору на питање који је датум. Уз изражавање сати употребљава се редни број у женском роду (подразумева се godzina). Разломке је Кошутић издвојио у посебну групу, наводећи да се као бројилац користи прост број, а као именилац редни (у тадашњој терминологији бројитељ и именитељ). У зависности од броја који стоји у бројиоцу, именилац ће бити у различитим падежима: ако је у бројиоцу број jeden, именилац ће бити у номинативу једнине; ако су у бројиоцу бројеви $d w a, t r z y$ или cztery, именилац је у генитиву множине, а од броја pięć па навише - у генитиву множине. И у случају разломака употребљава се женски род (подразумева се именица сzе̨ś́). Разломак се везује за цео број помоћу везника i, као и у нашем језику. На крају овог одељка Кошутић даје Примере за вежбање.

Последњем одељку Кошутић је дао наслов Остали бројеви. У овој групи издвојено је неколико типова: Мултипликативни бројеви, Пропорционални бројеви, Дистрибутивни бројеви, Бројни адверби и Неодређени бројеви.

У прву групу Мултипликативни бројеви Кошутић је укључио облик јеdnaki (данас архаизам), затим бројеве dwojaki, trojaki, czworaki,

${ }^{7}$ Нав. дело, стр. 101. 
pięcioraki до dziesięcioraki (уз напомену да се даљи бројеви не употребљавају). Група Пропорционалних бројева обухвата облике pojedynczy, podwójny, potrójny, poczwórny, poszóstny и такође напомену да се даљи бројеви не употребљавају. Као Дистрибутивне бројеве наводи варијантне облике po jednemu / po jednym за мушки и средњи род, и ро јеdnej за женски род (именица уз њих је у локативу једнине); po trzech, po czterech (именица је у акузативу множине), po pięciu, po stu за персонални облик (именица је у генитиву множине), po dwa (dwie), po cztery (у акузативу множине), po dziesięć, po sto (у генитиву множине), и напомиње да је уз збирне бројеве именица увек у генитиву множине. Бројни адверби су у

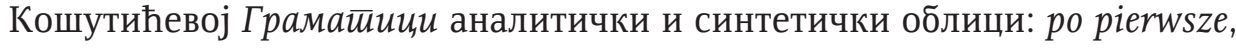
po drugie / po wtóre, po trzecie, po czwarte, данас архаично najprzód, raz, dwa razy, pięć razy, sto razy, odrazu (по тадашњем правопису; данас се пише одвојено: od razu), naraz, pewnego razu, pare / kilka razy, ani razu, na razie, po raz ostatni, razem, следеће конструкције: raz, drugi, или: raz po raz, raz w raz, или: to raz, to znów, или: jednym razem (данас само: razem), tym razem, od pierwszego razu, innym razem, или: za pierwszym, drugim, trzecim razem. Кошутић наводи и облик kroć и даје примере његове самосталне употребе или везано уз бројеве (jednokrotny, dwukrotny, pięciokrotny, dwudziestokrotny, stokrotny). Помиње и конструкције типа co godzina / co godzine, co miesiac, co trzy miesiace (уз које иде номинатив или акузатив) или coraz to lepiej. Последња група Неодређени бројеви обухвата облике ile, tyle, kilka, wiele, niewiele и за њих Кошутић даје промену, прво неперсоналну, а затим персоналну, помињући чињеницу да су се ови облици некада мењали по именичкој промени. Даје, такође, и промену сложених облика kilkanaście, kilkadziesiąt, kilka set (по старом правопису, данас: kilkaset), kilka tysięcy. У Напоменама подсећа да персонални облици од kilkanaście, kilkadziesiąt у номинативу и акузативу гласе: kilkunastu, kilkudziesięciu. Неодређену количину или број изражавају и облици mnóstwo, moc, masa, trocha (данас само: trochę). За облик para Кошутић објашњава да његово значење зависи од тога да је самостално (у том случају значи: пар), или захтева допуну (у том случају значи: неколико, и тада се мења као број $d w a$. Уколико су ови неодређени бројеви у функцији субјекта у реченици, они стоје у акузативу, а предикат је у једнини, у средњем роду и у безличном облику.

Поглавље посвећено бројевима завршава се Примерима који се налазе и на крају сваког одељка, и који одлично илуструју и поткрепљују теоријски део са Кошутићевим објашњењима написаним прецизним и јасним језиком. Партија посвећена бројевима и данас може да послужи као основ за учење граматике пољског језика. Управо се на категорији бројева у Кошутићевој Граматииии и поређењем са данашњом пољском језичком ситуацијом може извести драгоцен закључак у ком правцу је 
ишао развој пољског језика, који облици су се учврстили и опстали, који су задржали варијантне облике, који су постали у данашње време архаични, а који су потпуно нестали из употребе (и који су се нови, евентуално, појавили).

У једноме је Кошутић сасвим модеран. Будући да је он, од самог постављења за предавача Велике школе, у јануару 1895. године, а касније и као доцент, ванредни и редовни професор на Катедри за источне и западне словенске језике, држаао наставу из пољског, чешког и руског језика, то је на својим курсевима и у приручницима и уџбеницима истицао и сличности и разлике у промени бројева у пољском и руском језику. Уколико су постојали варијантни облици, наводио би и примере са облицима који се чашће јављају. Облике бројева је, наравно, поредио и са стањем у српском језику. Својом Грамайиком Кошутић је трасирао пут каснијим конфронтативним проучавањима пољског и српског језика, и тиме „није само започео синхронијска, конфронтативна проучавања српског језика у поређењу са другим словенским језицима, него је својим методом, који је звао диференцијални метод, увео у лингвистичку методологију нови приступ описима језика, који је приближно пола века касније у америчкој лингвистици, независно од Кошутићевог дела, назван контрастивна анализа, односно контрастивна лингвистика"

Професор Кошутић је држао тросеместралне курсеве руског и пољског језика све до почетка II светског рата. Методичку концепцију Кошутићеву наставио је после рата професор Ђорђе Живановић, од 1933. године до рата асистент за историју југословенске књњижевности код професора Павла Поповића ${ }^{9}$, а од 1954. године прво ванредни, а затим редовни професор за пољски језик и књижевност. Примарна област интересовања нашег Професора била је историја међусловенских књижевних и културних веза и, пре свега, српска и пољска књижевна историја, али и проблеми пољског и српског језика, будући да је Професор био изванредан зналац нашег језика (од 1951. је као доцент Позоришне академије предавао савремену српскохрватску акцентуацију, и исте те године објавио је књигу Проблеми йозорищног језика). Његово усмерење ка пољском језику и књижевности започето је по завршеним студијама када је школску годину 1932/1933. провео као стипендиста на усавршавању у Варшави, када је имао прилике да слуша, између осталог, и предавања из пољског језика код професора Дорошевског. По повратку из Пољске, као припрему за соколски слет у Варшави, који је требало да се

\footnotetext{
${ }^{8}$ Пипер П., Кошуйић, Раgован [у:] Одабране биографије, том V. Матица српска 2011, стр. 39.

${ }_{9}^{9}$ Топић М., Буњак П., Професору Ђорђу Живановићу у сйомен. Сто година полонистике у Србији. Београд 1996, стр. 45-57.
} 
одржи 1935. године, Професор је од јануара до јуна 1934.године одржао курс пољског језика у 23 лекције, које су исте године објављене у облику књиге Пракиичини уибеник йољскої језика. Осим ове књиге из 1934. године, објављена је и књига Пољски у 100 лекција 1971. године, која је, уз Професорова предавања, генерацијама студената полонистике служила и као одличан уџбеник за учење пољског језика. Нажалост, велику двотомну Грамайику йољскої језика, урађену на најбољим основама «кошутићевске» школе, Професор није успео да објави за живота, а покушаји да се тај рукопис објави постхумно није уродио плодом, јер је, нажалост, нестао или је уништен. Први том те необјављене Граматиике обухватао је Фонетику (са урађеним палатограмима), а други део Морфологију.

У приручнику Пољски у 100 лекиија професор је четири лекције посветио бројевима. У педесет деветом часу наводи просте бројеве приказане цифрама и графемама, за прва четири проста броја даје род и падешке облике. У оквиру промене простих бројева подсећа да се број jeden мења као придев, за број $d w a$ даје сва три облика промене (за мушка лица, за мушки и средњи род и за женски род), а за бројеве trzy и cztery даје промену за мушка лица и за остале. Следећи навод показује нам две ствари: прво, Професоров конфронтативни приступ билатерарног типа (од српског ка пољском и од пољског ка српском) ${ }^{10}$, и друго, јасно и језгровито речено све оно што је неопходно:

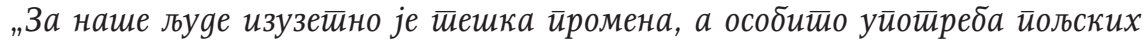
иростих бројева, јер се ко нас већ сасвим лако може рећи: оg gва сииуденйа

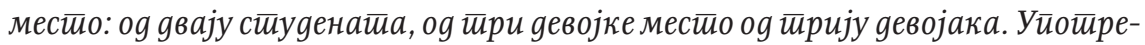
ба ће йак бийи: ако се уйотиребе бројеви dwaj, trzej, сzterej, онgа ће имении, бити у номинаиииву множине: dwaj doktorzy, czterej koledzy, profesorowie, kapitanowie и сл. Онgа ће ілаїол gоћи у множину: dwaj panowie przyszli, id ulicą. Ако се у номинатииву уйотиреби облик dwóch, trzech, czterech, онgа

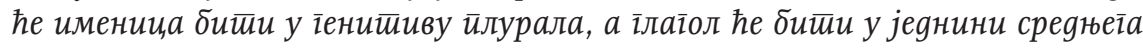
poga, оgносно йо је безлична констирукиија: dwóch panów przyszło do nas, idzie ulicą." ${ }^{11}$

За персонални облик броја рięć професор Живановић наводи, осим облика pięciu, за који каже да је то облик за све падеже, и варијантни облик ріе̨сіота који се употребљава само у инструменталу. Обраћа пажњу и на изговор: за број 60 у персоналном облику sześćdziesięciu даје у загради напомену (изі̄оворu: szeździesięciu!), а за бројеве piętnaście и dziewiętnaście указује на то да се назал предњега реда $е$ изговара деназа-

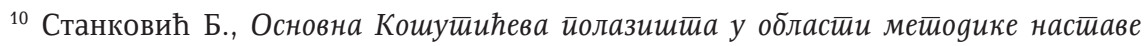
инословенских језика у срйској среgини. Сто година полонистике у Србији. Београд 1996, стр. 39-45.

${ }^{11}$ Живановић Ђ., Пољски у 100 лекиија. Просвета, Београд 1971, стр. 161. 
лизовано, као чист вокал е. Код сложених бројева на примеру dwudziestu sześciu показује како се мењају цифре јединица и десетица. Подвлачи да се само број jeden не мења у сложеним бројевима (овај случај углавном представља проблем за наше студенте), и даје следеће примере: pięćdziesiąt jeden osób, z pięćdziesięcioma jeden osobami.

Шездесети час је посвећен употреби простих бројева. Одмах се истиче: „Слагање именица с бројевима је друкчије него код нас”12. Уз бројеве $d w a$, trzy, cztery употребићемо номинатив плурала, а уз pięć па навише генитив плурала. Даје затим персоналну и неперсоналну промену броја рięć уз именице. Напомиње да се у сложеним бројевима мењају само цифре десетица и јединица (нпр. tysiąc dwieście siedemdziesiąt pięć, tysiąc dwieście siedemdziesięciu pięciu). Показује како се врше рачунске операције сабирања и одузимања бројева. Указује на употребу облика везаних за означавање година: jeden rok, dwa lata, pięć lat, mam dwadzieścia jeden lat.

Шездесет први час обухвата редне бројеве (дати су бројеви од облика pierwszy до tysięczny / tysiaczny), уз подсећање да вишецифрени редни бројеви имају облике редних бројева само у цифрама десетица и јединица (sto dwudziesty pierwszy, tysiac osiemset trzydziesty piąty). У вези са редним бројевима је и исказивање времена за које професор Живановић даје примере: „На питање: która godzina? - одговара ce: pierwsza, druga, trzecia итд. А на питање: o której (godzinie)? - одговара се: о pierwszej, o drugiej, o trzeciej итд." ${ }^{\prime 3}$. Даје различите варијанте изражавања времена (или, како стоји у поднаслову: Казивање часова).

У шездесет другом часу показано је казивање датума. Професор подсећа да се за датум поставља питање: którego mamy dziś? - на које се одговара, на пример: dwudziestego drugiego lipca. Конструкције везане за изражавање датума могу садржати генитив сингулара (dnia ósmego lutego tysiąc dziewięćset sześćdziesiatego trzeciego roku) или локатив са предлогом $w$ (w dniu ...).

Шездесет трећи час обухвата разломке $(1 / 3$ - jedna trzecia, 4/7 cztery siódme, 3/24 - trzy dwudzieste czwarte, 5/9 - pięć dziewiątych, 8/35 - osiem trzydziestych piatych), збирне бројеве (од облика dwoje до облика jedenaścioro, од којих се даје промена за dwoje и czworo) и неодређене бројеве parę, kilka, paręnaście, kilkanaście, parędziesiąt, kilkadziesiąt, paręset, kilkaset (са преводним еквивалентима), у оквиру којих се дају и бројни изрази ile, tyle, wiele, niewiele.

Какво место данас заузимају бројеви у наставипољског језика као страног?

\footnotetext{
${ }^{12}$ Нав. дело, стр. 163.

${ }^{13}$ Нав. дело, стр. 166.
} 
Полазећи од методичких основа које су београдској полонистици поставили Радован Кошутић и Ђорђе Живановић, њихови ученици који су данас учитељи неким новим генерацијама настоје да у својим приступима језичкој материји коју презентују студентима сачувају све оно што се показало као добро и ефикасно и што је опстало до данашњих дана.

Са бројевима у пољском језику студенти се сусрећу још на првим часовима практичне наставе, у раду са лектором. Један од шпанских лектора са Катедре за иберијске студије је за време боравка у нашој земљи имао обичај да сваку генерацију нових студената упознаје са шпанским језиком на својим првим лекторским вежбама зако што би по уласку у учионицу изговорио реченицу: Los numerales son muy importantes. Имајо је у виду, свакако, чињеницу да бројеви у језику не могу имати неку замену и да их је због тога неопходно савладати већ на почетку учења страног језика. Из теоријске наставе, у оквиру предмета Пољски језик 1 и Пољски језик 2 (који обухватају предавања из фонетике, фонологије и правописа), потребно је у примерима бројева piętnaście и dziewiętnaście истаћи деназализован изговор назала предњега реда $е$, затим свакако давати примере простих бројева као илустрацију обележавања мекоће у пољском језику (алтернације - обележавање помоћу графичког знака $i$ у позицији испред вокала и помоћу дијакритичког знака у финалној позицији и у позицији испред консонанта), на примерима бројева илустровати асимилације по звучности и сл. У оквиру ортографије подвући да се, за разлику од српског, у пољском језику иза редних бројева не ставља тачка. У вези са овим последљим, обавезно треба обраћати пажњу на сличности и разлике у систему бројева у српском и пољском, а пожељно би било у то укључити и руски. И када су бројеви у питању, сматрамо да је и за ову категорију драгоцено да се не раздваја синхронија од дијахроније, јер ћемо и бројеве лаксе савладати ако знамо од чега је неки облик настао и како се током времена развијао.

У оквиру предмета Пољски језик 3 бројеви се традиционално проучавају као морфолошка категорија. Даје се њихова најчешћа класификација и промена по падежима. Посвећује се, такође, пажња ономе што и професор Кошутић и професор Живановић дефинишу као „употреба бројева", а што заправо означава слагање бројева уз именицу уз коју стоје у роду, броју и падежу. Међутим, посматрање бројева углавном као морфолошке категорије у данашње време није довољно. Природа бројева као језичке категорије (ово подвлачимо више пута, јер је изражавање неке величине својственије природним наукама) је таква да се они могу посматрати им проучавати из више различитих аспеката. Неки од тих аспеката могу да буду творба или грађење бројева, а свакако их треба посматрати у реченици, као синтаксичку категорију. Теоријска разматрања ове категорије синхронизују се са практичним асистент- 
ским и лекторским вежбањима уз коришћење различитих приручника који у свом садржају управо имају вежбе овога типа. ${ }^{14}$

Посвећивање довољне пажње категорији бројева у језику допринеће томе да се избегне извесна доза несигурности када је ова врста речи у питању, и да бројеве почнемо да прихватамо као значајан и неопходан део језика коме они потпуно равноправно са осталим врстама речи и припадају.

\section{ЛИТЕРАТУРА}

Живановић Ђ., Пољски у 100 лекиија. Просвета, Београд 1971, стр. 331.

Јовановић Г., Почеии и развој иолонистиике на беоіраяском универзииеейу. Сто година полонистике у Србији, Београд 1996, стр. 13-19.

Кошутић Р., Грамайика йољскоїа језика. Београд 1898, стр. 201.

Kryżan-Stanojević B., Sawicka I., Ćwiczenia zfleksji języka polskiego dla cudzoziemców. Toruń 2007, s. 217.

Пипер П., Кошуш̄ић, Раgован [у:] Одабране биографије, том V. Матица српска 2011, стр. 38-39.

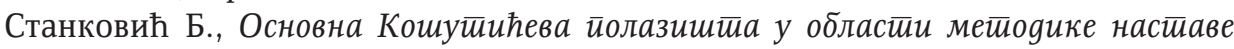
инословенских језика у срйској среgини. Сто година полонистике у Србији. Београд 1996, стр. 39-45.

Топић М., Буњак П., Професору Ђорђу Живановићу у сйомен. Сто година полонистике у Србији. Београд 1996, стр. 45-57.

Mirjana Kostić Golubičić

NUMBERS IN TEACHING ON THE BELGRADE POLONISTICS

\section{Summary}

The subject of interest in the work is the linguistic cathegory numbers in theoretical and practical study of the Polish language. Numbers are analyzed as a didactic unit in the Grammar of the Polish language by Professor Radovan Košutić, the founder of polonistic studies at the Belgrade University, as well as in the Polish in 100 lessons by Professor Đorđe Živanović. A more modern aproach would imply

\footnotetext{
${ }^{14}$ Неки од таквих уџбеника су: Mędak S., Liczebnik też się liczy. Gramatyka liczebnika z ćwiczeniami. Universitas 2013, s. 252; Iglikowska T., Ćwiczenia gramatyczno-leksykalne. Wydawnictwa Uniwersytetu Warszawskiego 1995, s. 297; Kryżan-Stanojević B., Sawicka I., Ćwiczenia z fleksji języka polskiego dla Cudzoziemców. Toruń 2007, s. 217, и др.
} 
more complex study of numbers from the morphological, formative, and syntactic aspects.

Key words: numbers, morphology, word formation, syntax, etymology 